Canadian University Music Review

Revue de musique des universités canadiennes

\title{
The Magic Wand of the Wagnerians: Musik als Ausdruck
}

\section{Stephen McClatchie}

Numéro 13, 1993

URI : https://id.erudit.org/iderudit/1014297ar

DOI : https://doi.org/10.7202/1014297ar

Aller au sommaire du numéro

\section{Éditeur(s)}

Canadian University Music Society / Société de musique des universités canadiennes

\section{ISSN}

0710-0353 (imprimé)

2291-2436 (numérique)

\section{Découvrir la revue}

\section{Citer cet article}

McClatchie, S. (1993). The Magic Wand of the Wagnerians: Musik als Ausdruck. Canadian University Music Review / Revue de musique des universités

canadiennes, (13), 71-92. https://doi.org/10.7202/1014297ar

\section{Résumé de l'article}

As is well-known, throughout most of the nineteenth century the defence of Wagner's music was not undertaken on the same grounds on which it was attacked. Critics such as Ludwig Bischoff and Eduard Hanslick attacked Wagner's music for its alleged "formlessness" and harmonic illogicalities, while Wagner's partisans countered with appeals to vaguer criteria of beauty and truthfulness, couched generally in leitmotivic terms, often focusing on the so-called "symphonic web" of Wagner's late works. One particular strategy is encapsulated by the phrase "Musik als Ausdruck," which forms the basis of a number of late nineteenth- and early twentieth-century monographs and articles about Wagner's works. Musical gestures were held to encode a particular emotional state and to reawaken that state in the listener, who would intuit the "meaning" of the gesture instinctively; within such an aesthetic, music was held to represent the essence of phenomenon, the "thing-in-itself."

This article attempts to provide an account of the dual foundations of this aesthetic paradigm in philosophy and science, as manifested by Arthur Schopenhauer's Die Welt als Wille und Vorstellung and by Friedrich von Hausegger's Die Musik als Ausdruck respectively, and suggests that the resulting position - as articulated by Hans von Wolzogen and Curt Mey - is not only incompatible with but also incomparable to that of the formalists. The reconciliation of these two positions would not take place until the 1920s and 1930s with the work of Alfred Lorenz.
All Rights Reserved @ Canadian University Music Society / Société de musique des universités canadiennes, 1993
Ce document est protégé par la loi sur le droit d'auteur. L’utilisation des services d'Érudit (y compris la reproduction) est assujettie à sa politique d'utilisation que vous pouvez consulter en ligne.

https://apropos.erudit.org/fr/usagers/politique-dutilisation/ 


\title{
THE MAGIC WAND OF THE WAGNERIANS: MUSIK ALS AUSDRUCK*
}

\author{
Stephen McClatchie
}

Throughout most of the nineteenth century the defence of Wagner's music was not undertaken on the same grounds on which it was attacked. Critics such as Ludwig Bischoff and Eduard Hanslick attacked Wagner's music for its alleged "formlessness" and harmonic illogicalities, while Wagner's partisans countered with appeals to different criteria of beauty and dramatic truthfulness, couched generally in leitmotivic terms, and often focusing on the so-called "symphonic web" of Wagner's late works. ${ }^{1}$

One particular defence is encapsulated by the phrase "Musik als Ausdruck" - music as expression - which forms the basis for a number of later nineteenthand early twentieth-century monographs and articles about Wagner's works. Musical gestures were held to encode a particular emotional state and to reawaken that state in the listener, who would intuit the "meaning" of the gesture instinctively; within such an aesthetic music was held to represent the essence of phenomenon, the "thing-in-itself." I want to touch briefly on the dual foundations of this aesthetic paradigm in philosophy and science, as manifested by Schopenhauer and Friedrich von Hausegger respectively, and offer two examples of it in use, in writings by Hans von Wolzogen and Curt Mey. The following is intended as an introduction to the expressive aesthetic position as it relates primarily to Wagner and the reception of his works in the decades immediately following his death in 1883. It makes no attempt to assess the evolution of this aesthetic position in the latter half of the century, or its impact on others such as Liszt, Berlioz, or Brendel, who are generally counted with Wagner as the musical "progressives."

* Earlier versions of this paper were presented at the University of Western Ontario Ph. D. Colloquium Series in September 1991 and at the annual meeting of the Canadian University Music Society in Charlottetown, Prince Edward Island, June1992. I wish to thank Jeffrey Stokes and Roger Parker for their helpful comments and suggestions on earlier drafts.

1 For a concise account of the history of Wagnerian analysis, see Carolyn Abbate and Roger Parker, "Introduction: On Analyzing Opera," in Analyzing Opera: Verdi and Wagner, ed. Carolyn Abbate and Roger Parker (Berkeley and Los Angeles: University of California Press), 1-24. 


\section{The Philosophical Foundation: Arthur Schopenhauer}

Schopenhauer's principal work, Die Welt als Wille und Vorstellung (1818), follows in the tradition of Kantian (and ultimately Platonic) idealism which postulates two levels of reality for all things, that of "appearance" or "phenomena" and that of "essence" or "noumena." Appearance is held to be deceptive, revealing only the exterior form of things, and leaving the "thing-in-itself" [Ding an sich] untouched. His philosophy may be termed idealistic, as it holds the mind and spiritual values to be primary. It is also highly subjective, as the first sentence of Die Welt als Wille und Vorstellung reveals: "The world is my idea."2 Through reason - active perception, ordering, and synthesising of fragmentary bits of experience - I create my own representation or idea of the world (the German word Vorstellung can mean both); that is, the world only exists as I understand it. Put another way, all perceived phenomena are merely various grades of objectification of the "thing-in-itself."

Schopenhauer's main departure from Kant is his notion that the primary force in the world, the principal "thing-in-itself" is not a real but rather an irrational, insatiable drive known as the will. It is objectified (i.e. made visible, present) in all phenomena of the world. The ceaseless striving of the will is held to be the root of all problems and suffering in the world; life is seen as an endless, meaningless round of striving and suffering, with pleasure only the momentary release from pain. True freedom results from one's resignation from life and desire: one must simply stop wanting.

Schopenhauer's treatment of music comes as the culmination of his consideration of the fine arts, each of which are said to embody various grades of the objectification of the will. All of the arts except music are understood as a reflection or copy of the "Platonic Ideas" behind all phenomena. Music, however

stands alone, quite cut off from all the other arts. In it we do not recognise the copy or repetition of any Idea of existence in the world ... [I]t is such a great and exceedingly noble art, its effect on the inmost nature of man is so powerful, and it is so entirely and deeply understood by him in his inmost consciousness as a perfectly universal language, the distinctness of which surpasses even that of the perceptible world itself. ${ }^{3}$

Already Schopenhauer is aligning himself with the romantic trope of music as the highest of all the arts. Music is a culmination, a depiction of the world itself.

2 Arthur Schopenhauer, The World as Will and Idea, 3 vols., trans. R.B. Haldane and J. Kemp (London: Routledge \& Kegan Paul) I, 1.

3 Schopenhauer, The World as Will and Idea, I, 330. 
He later explicitly states that the addition of music to any "scene, action, event, or surrounding seems to disclose to us its most secret meaning, and appears as the most accurate and distinct commentary upon it." ${ }^{\text {"S }}$ Shopenhauer believes that a complete explanation or conceptualisation of music would be the equivalent of philosophy; in a parody of Leibnitz, he expresses this as follows: "music is an unconscious exercise in metaphysics in which the mind does not know it philosophises."5

Schopenhauer sees in music a direct copy of the Will itself, unmediated by the Platonic Ideas. Music, essentially non-representational, stands apart from the other arts, independent of the world of appearance. Instead of reflecting, or objectifying the Will second-hand, through ideas, it does so directly, without mediation:

The (Platonic) Ideas are the adequate objectification of will. To excite or suggest the knowledge of these by means of the representation of particular things (for works of art themselves are always representations of particular things) is the end of all the other arts, which can only be attained by a corresponding change in the knowing subject. Thus all these arts objectify the will indirectly only by means of the Ideas; and since our world is nothing but the manifestation of the Ideas in multiplicity, through their entrance into the principium individuationis..., music also, since it passes over the Ideas, is entirely independent of the phenomenal world, ignores it altogether, could to a certain extent exist if there was no world at all, which cannot be said of the other arts... Music is thus by no means like the other arts, the copy of the Ideas, but the copy of the will itself, whose objectivity the Ideas are. This is why the effect of music is so much more powerful and penetrating than that of the other arts, for they speak only of shadows, but it speaks of the thing itself. ${ }^{6}$

In a later clarification of this passage, Schopenhauer asserts that this is the reason that music acts directly upon the feelings, passions, and emotions (the will) of the hearer, quickly raising or changing them. ${ }^{7}$

In what follows, Schopenhauer draws an analogy between different musical phenomena and the various grades of objectification of the will in the world (which he has already traced by this point.) For example, he compares the lowest tones of the bass to "the lowest grades of the objectification of the will,
4 Ibid., I, 339.
5 lbid., I, 342.
6 Ibid., 1, 332-33.
7 Ibid., III, 232. 
unorganised nature, the mass of the planet." ${ }^{8}$ Melody is the highest degree of the will's objectification. Schopenhauer describes the process of melodic motion in terms of the will's appetite, its satisfaction and perpetual renewal, analogous to the melodic resolution of non-harmonic tones or modulation away from and back to a tonic.

If music acts directly upon our will - that is, upon our feelings and emotions rather than our reason - what is the result of this action? Schopenhauer again may be linked to other romantic writers when he asserts that the feelings aroused by music are of an indistinct, imprecise nature:

But is must never be forgotten ... that music ... never expresses the phenomenon, but only the inner nature, the in-itself [Ansich] of all phenomena, the will itself. It does not therefore express this or that particular and definite joy, this or that sorrow, or pain, or horror, or delight, or merriment, or peace of mind; but joy, sorrow, pain, horror, delight, merriment, peace of mind themselves, to a certain extent in the abstract, their essential nature, without accessories, and therefore without their motives. ${ }^{9}$

That is, the feelings aroused by music are of an indistinct, imprecise nature. But music itself, as will, belongs to the noumenal realm; it is "a perfectly universal language, the distinctness of which surpasses even that of the perceptual world itself." are attached to music as in song or opera, it is only out of a desire to embody music in an analogous example; the resulting construct stands in relation to the universal language of music as a random illustration to a general concept. Schopenhauer is adamant that words occupy a subordinate position to the music. The music does not express the words, but rather the universal which lies behind the words. They are "a foreign addition, of subordinate value, for the effect of the tones is incomparably more powerful, more infallible and quicker than that of the words." 11

Schopenhauer's aesthetic is clearly aligned with common romantic tropes about music: music as the highest of the arts, music expressing the inexpressible. Schopenhauer also touches on another typically romantic figure: the notion of composer-as-genius whose works are pure inspiration, conceived unconciously, often while dreaming.

\footnotetext{
8 lbid., I, 333.

9 Ibid., I, 338.

10 Ibid., I, 330.

11 Ibid., I, 323.
} 
Schopenhauer argues that through intellect or reason, it is possible to escape the evil of endless willing and rise above the world of will. One must see things without subjectivity, as objects of understanding as opposed to objects of desire - without personal interest. Contemplation of works of art provides momentary escape from the workings of the will; by seeing something as beautiful we are seeing the universal in the particular, i.e., we are catching a glimpse of the Platonic Idea of which the object of our contemplation is an instantiation. Although this capacity to recognise the Idea through the contemplation of works of art exists in all men, it does so to the highest degree in genius. Genius is the highest form of this will-less knowledge, the clear and impartial perception of the objective, the essential, and the universal. ${ }^{12}$

In a later passage, Schopenhauer explicitly applies this notion of genius to composers:

The composition of melody, the disclosure in it of all the deepest secrets of human willing and feeling, is the work of genius, whose action, which is more apparent here than anywhere else, lies far from all reflection and conscious intention, and may be called an inspiration ... The composer reveals the inner nature of the world, and expresses the deepest wisdom in a language which his reason does not understand ... Therefore in the composer, more than in any other artist, the man is entirely separated and distinct from the artist. ${ }^{13}$

Of course, Schopenhauer is known to musicians principally because of Wagner's rather self-conscious acceptance of his ideas from the time he discovered them in the 1850s while struggling with the dramaturgy of the Ring poem. Wagner's Beethoven Festschrift of 1871 stands as testimony to his conversion to the Schopenhauerian aesthetic.

In Beethoven, Wagner seizes particularly on Schopenhauer's dream theory. Following Schopenhauer's notion of two worlds - a waking (phenomenal) and a dreaming (noumenal) - Wagner posits a light-world [Lichtwelt] distinct from a sound-world [Schallwelt]; music arises unconsciously from this internal sound-world, accessible through the organ of dreams [Traumorgan].

For as the inwardly turned consciousness in the phenomenon [of clairvoyance] attains the actual power of sight, (that is, the capacity of seeing where our waking consciousness, turned towards day, only darkly senses the

12 Ibid., I, §36-38 and II, chapter 31.

13 Ibid., I, 336. 
powerful basis of our will's emotions) so, from out of this night, tone will penetrate into actual waking perception as a direct expression of the will. ${ }^{14}$

Wagner's account in Mein Leben of the putative La Spezia vision leading to the composition of the Das Rheingold prelude concludes with a similar sentiment: "I also saw immediately precisely how it was with me: the vital flood would come from within me, and not from without."15

The above description of musical inspiration is completely in line with Schopenhauer: creative (as opposed to consumptive) access to the noumenal world of dreams, Wagner's Schallwelt, is given only to geniuses; the composer's inspiration is different from other artist's:

Enlightenment concerning the essence of music as an art, as difficult as such a task is, we believe may be obtained best through consideration of the creations of an inspired musician. In many respects this must be fundamentally different from that of other artists. Of the latter we have had to acknowledge that pure contemplation of the object, free of will, must first have taken place, just as it is again produced by the effect of the displayed work of art on the viewer. Such an object, however, which he is to raise to the Idea through pure contemplation, does not present itself to the musician at all; for his music is itself an Idea of the world in which the world shows its essence directly, whereas in those other arts it is shown, but first mediated by knowledge. This can only be understood in that the individual will, silenced in the plastic artist through pure contemplation, awakens in

14 "Gelangt in jenem Phänomen [Hellsehen] nämlich das nach Innen gekehrte Bewußtsein zu wirklicher Hellsichtigkeit, d.h. zu dem Vermögen des Sehens dort, wo unter wachendes, dem Tage zugekehrtes Bewußtseins nur den mächtigen Grund unserer Willensaffekte dunkel empfindet, so dringt aus dieser Nacht aber der Ton in die wirklich wache Wahrnehmung, als unmittelbare Äußerung des Willens" (Richard Wagner, Gesammelte Schriften und Dichtungen, 4th ed., 10 vols. [Leipzig: Walter Tiemann, 1907], IX, 68. While all translations are the work of the present author, for Wagner's prose I have consulted William Ashton Ellis's translation (Richard Wagner's Prose Works, 8 vols., trans. William Ashton Ellis [London: Routledge and Kegan Paul, 1892-99; reprinted New York: Broude Bros., 1966]) but felt free to modify liberally. For this reason, I shall not bother to cite Ellis henceforth.

15 Richard Wagner, My Life, trans. Andrew Grey, ed. Mary Whittall (Cambridge: Cambridge University Press, 1983), 499. As in so many occasions in Mein Leben, it is difficult to separate fact from fiction, or at least retroactive myth-making on the part of Wagner while he was dictating his autobiography to Cosima in 1865 . The passage in question corresponds to such a degree with Schopenhauer's dream theory and the role of genius that one is tempted to accuse Wagner of mythologising the beginning of the Ring's composition. This is certainly the view of John Deathridge; see his “Wagner's Sketches for the 'Ring'," Musical Times 118 (May 1977): 38789. 
the musician as universal will, and - above and beyond all contemplating recognises itself as such in its real consciousness of self ... This enormous flooding of all the boundaries of appearance must necessarily call forth a state of ecstasy in the inspired musician with which no other can be compared; in it the will recognises itself as the almighty will in general: it need not mutely hold itself back in the face of contemplation, but announces itself loudly as the conscious Idea of the world. ${ }^{16}$

Following Schopenhauer, Wagner gives music first place amongst the arts. Music alone reveals the world as it truly is. The compositional process is presented in terms of inspiration, of genius. But what then has happened to Wagner's notion of the Gesamtkunstwerk, the dialectically inevitable fusion of all the arts, not just music? In Beethoven, Wagner seems to side step the question; he never recants the central thesis of Oper und Drama, rather he likens all the other arts to music, enclosing them within her all-encompassing skirts.

Music, which does not represent the Ideas inherent in the world's phenomena, is itself a comprehensive Idea of the world; it completely includes the drama in itself, for drama again expresses the world's only idea on the same level as that of music. Just as a drama does not portray human characters, but lets them represent themselves directly, so the motives of music give us the character of all the world's appearances according to their innermost essence. The motion, formation, and evolution of these motives is not only analogously related to the drama, but a drama representing the Idea can only be understood with perfect clearness through those moving, forming, and

16 "Eine Aufklärung über das Wesen der Musik als Kunst glauben wir, so schwierig sie ist, am sichersten auf dem Wege der Betrachtung des Schaffens des inspirirten Musikers zu gewinnen. In vieler Beziehung muß dieses von demjenigen anderer Künstler grundverschieden sein. Von jenem hatten wir anzuerkennen, daB ihm das willenfreie, reine Anschauen der Objekte, wie es durch die Wirkung des vorgeführten Kunstwerkes bei dem Beschauer wieder hervorzubringen ist, vorangegangen sein müsse. Ein solches Objekt, welches er durch reine Anschauung zur Idee erheben soll, stellt sich dem Musiker nun aber gar nicht dar; denn seine Musik selbst ist eine Idee der Welt, in welcher diese ihr Wesen unmittelbar darstellt, während in jenen Künsten es, erst durch das Erkennen vermittelt, dargestellt wird. Es ist nicht anders zu fassen, als daß der im bildenden Künstler durch reines Anschauen zum Schweigen gebrachte individuelle Wille im Musiker als universeller Wille wach wird, und uber alle Anschauung hinaus sich als solcher recht eigentlich als selbstbewußt erkannt ... Diese ungeheure Überfluthung aller Schranken der Erscheinung muB im begeisterten Musiker nothwendig eine Entzückung hervorrufen, mit welcher keine andere sich vergleichen ließe: in ihr erkennt sich der Wille als allmächtiger Wille überhaupt: nicht stumm hat er sich vor der Anschauung zurückzuhalten, sondern laut verkündet er sich selbst als bewuBte Idee der Welt" (Wagner, Gesammelte Schriften und Dichtungen, IX, 72-73). 
evolving musical motives. Accordingly we would not error were we to define music as man's a priori qualification for shaping drama in general. ${ }^{17}$

But if music is thus superior, then by implication, the other arts are inferior, or at least subordinate. And so we approach Schopenhauer once more: the words are merely a help, a guide, while the "essence" of the drama is revealed by the music. Something of this may be glimpsed in Wagner's later description of music drama as "ersichtlich gewordene Thaten der Musik," deeds of music made visible. ${ }^{18}$ The true equation is from inside out: outward manifestation of internal essence.

Schopenhauerian thought, often reflected through Wagner's prose and musical works, is one pillar buttressing the expressive aesthetic position. It also provides much of the cement for the second pillar: Friedrich von Hausegger's aesthetic of music as expression.

\section{The Scientific Foundation: Friedrich von Hausegger}

Two events in the middle decades of the nineteenth-century proved decisive for the current of thought in the second half of the century: first, the publication in 1842 of the final volume of Auguste Comte's "Positivist Manifesto," the Cours de Philosophie positive; second, the publication in the late 1850s of Charles Darwin's theories of evolution. ${ }^{19}$

The positivistic method emphasises the importance of empirical evidence as the source of all knowledge, and eliminates from consideration any kind of entity

17 "Die Musik, welche nicht in den Erscheinungen der Welt enthaltenen Ideen darstellt, dagegen selbst eine, und zwar eine umfassende Idee der Welt ist, schließt das Drama ganz von selbst in sich, da das Drama wiederum selbst die einzige der Musik adäquate Idee der Welt ausdrückt ... Wie das Drama die menschlichen Charaktere nicht schildert, sondern diese unmittelbar sich selbst darstellen läßt, so giebt uns eine Musik in ihren Motiven den Charakter aller Erscheinungen der Welt nach ihrem innersten An-sich. Die Bewegung, Gestaltung und Veränderung dieser Motive sind analogische nicht nur einzig dem Drama verwandt, sondern das die Idee darstellende Drama kann in Wahrheit einzig nur durch jene so sich bewegenden, gestaltenden und sich verändernden Motive der Musik vollkommen klar verstanden werden. Wir dürften somit nicht irren, wenn wir in der Musik die aprioristische Befähigung des Menschen zur Gestaltung des Drama's überhaupt erkennen wollten" (Wagner, Gesammelte Schriften und Dichtungen, IX, 105-6).

18 Wagner, Gesammelte Schriften und Dichtungen, IX, 306, “Über die Benennung 'Musikdrama'."

19 For a concise introduction to the age, see the introductions provided for the source readings in Bojan Bujić, ed., Music in European Thought 1851-1912 (Cambridge: Cambridge University Press, 1988), and Edward Lippman, ed., Musical Aesthetics: A Historical Reader, vol. 2: The Nineteenth Century (Stuyvesant: Pendragon Press, 1988). 
which lies beyond the reach of empirical investigation. It is based on the assumption that it is possible to distinguish between facts and values, and utterly rejects the latter. Since matters such as ultimate causes and origins generally may not be proved empirically, positivists tend to restrict inquiries to "matters of fact", or to determination of the "laws of nature." Theories are advanced on the basis of assembled, verified, and classified data. Essentially it is the methodology of the natural sciences extended to society at large, and its reach was long in the nineteenth century. ${ }^{20}$

Alongside the new positivistic spirit in the social sciences and humanities was a firm adherence to the principle of evolution. One only need think of the vast number of historical studies written in terms of "forerunners" and "followers" to see this principle at work. ${ }^{21}$ Evolutionists argue that history, science, and art progress toward a greater perfection, from simpler to more complex forms, from imperfect ideas to more perfect ones. It is a curious paradox of positivism that researchers soon felt obliged to inquire into the causes or origins of the phenomena under investigation in order to complete the narrative of evolutionary progress, for, before they knew it, they were once again mired in the murky depths of speculation. ${ }^{22}$ Following Darwin and Spencer, very often the discovery of origins was held to be the key to understanding the essence of phenomena; this is indeed the case with Hausegger.

To Hausegger, an ardent Wagnerian, Wagner's music dramas represented the apex of the history of music. In these works, the true inner essence of music was revealed for the first time. Hausegger's Schopenhauerian principles are made explicit in an 1878 book entitled Wagner und Schopenhauer. Indeed, Wagner and Schopenhauer are the two constants in Hausegger's work; in fact, it would not be an exaggeration to see much of Hausegger's mature work as an attempt to prove scientifically a Wagnerian Weltanschauung.

In Die Musik als Ausdruck, Hausegger follows a positivistic methodology indebted to theories of evolution in an attempt to prove his theory that "the essence of music is expression - expression refined and raised to the highest

20 On the influence of positivistic thought on nineteenth-century science, see chapter five of David Oldroyd, The Arch of Knowledge: an Introductory Study of the History of the Philosophy and Methodology of Science (New York and London: Methuen, 1986).

21 Bujić (Music in European Thought 1851-1912, 306) argues that "under the encouraging protection of the positivist spirit and with added enthusiasm following the emergence of Darwin's theory of evolution, theories of biological evolution were simply transferred to the arts."

22 On the paradoxical question of "origin" in the nineteenth century, see Michel Foucault, The Order of Things: An Archaeology of the Human Sciences (New York: Random House, 1970), 328-35. 
power of effectiveness."23 This aesthetic position defended by Hausegger was also that of the Wagnerians, and Die Musik als Ausdruck became the primary scientific justification for the Bayreuth Circle. It first appeared serially in the house paper, the Bayreuther Blätter, in 1884, and Hans von Wolzogen, the Blätter's editor, elsewhere refers to Hausegger as "one of our philosophers and aestheticians." 24

Hausegger aligns himself with the tradition stemming from Rousseau in which music's origins are traced back to the first vocal utterances of primitive peoples. ${ }^{25}$ In such theories, the emission of sound is linked with a state of heightened emotion; together these mark the ultimate origin of music. Music is seen as a consequence - of and dependent upon - a physical-spiritual condition (emotion); it follows speech on a hypothetical evolutionary hierarchy. In the words of the Hausegger scholar Ernst-Joachim Danz, "Music is nothing but sound as a consequence of a physical-spiritual state of agitation, progressively modified with communicative intention throughout the course of human history." 26

When Hausegger discusses the relationship of the body and music, he does so in a completely literal manner. In this he differs from most of his nineteenthcentury counterparts, such as Wagner and Nietzsche, who mean the relationship to be metaphorical. ${ }^{27}$ Hausegger argues that the body has a causal relationship

23 "Das Wesen der Musik ist Ausdruck, geläuterter, zur edelsten Wirkung gesteigerter Ausdruck" (Friedrich von Hausegger, Die Musik als Ausdruck, 2nd ed. [Vienna: Konegen, 1887], 209).

24 In an unpublished letter to Hausegger of 14 May 1897, cited by E. J. Danz, "Richard Wagner und Friedrich von Hausegger: Der Meister und sein Ästhetiker in Graz," in Richard Wagner 18131883: Die Rezeption im 19. und 20. Jahrhundert, Gesammelte Beiträge des Salzburger Symposiums, ed. Ullrich Müller, Franz Hundsnurscher, and Cornelius Sommer (Stuttgart: Hans Dieter Heinz, 1984), 270. In this work, Danz also discusses the question whether Hausegger ought to be regarded as a Wagner epigone; for more on this question, see also Ernst-Joachim Danz, Die Objektlose Kunst: Untersuchungen zur Musikästhetik Friedrich von Hauseggers (Regensburg: Gustav Bosse, 1981), chapter 12.

25 The source is Jean-Jacques Rousseau's Essai sur l'origine des langues (Paris: A. Belin, 1817). The Essai occupies a significant place in the formulation of deconstruction; see Jacques Derrida, Of Grammatology, trans. Gayatri Chakravorty Spivak (Baltimore: Johns Hopkins University Press, 1976) and Paul De Man, "The Rhetoric of Blindness: Jacques Derrida's Reading of Rousseau" in Blindness and Insight (Minneapolis: University of Minnesota Press, 1983).

26 "Die Musik ist nicht anderes als der im Verlauf der Menschheitsgeschichte sich progressive differenzierende Laut als Folge eines körperlich-seelischen Erregungszustandes in kommunikativer Intention" (Danz, "Richard Wagner und Friedrich von Hausegger," 267-68).

27 Friedrich Nietzsche, The Birth of Tragedy, trans. Walter Kaufmann, in Basic Writings of Nietzsche (New York: Random House, 1968). On this metaphorical relationship, see Tilottama Rajan, "Language, Music, and the Body: Nietzsche and Deconstruction," in Intersections: Nineteenth-Century Philosophy and Contemporary Theory, ed. Tilottama Rajan and David Clark (Albany: SUNY Press, forthcoming). I wish to thank Dr. Rajan for providing me with a copy of this paper. 
with music. For example, the twin parameters of pitch and rhythm originate directly in the body: the former from a change in feeling or emotion which causes a deviation from the normal speaking tone, and the latter from the shift of body weight from one leg to another. ${ }^{28}$

To Hausegger, music forms the phenomenal outside of the lived-through inside of a feeling. It is the means by which this feeling is made audible. ${ }^{29} \mathrm{It}$ follows that for each distinct internal emotion there is an equally distinct external manifestation. There is no difference between an emotion expressed musically and one which remains purely physical and psychological. Given such a conception of music, it is also immaterial whether or not a specific piece has words.

The nascent discipline of psychology (foreshadowed by Schopenhauer's dream theory) becomes an important secondary scientific basis for Hausegger's theory when he maintains that the physical movements under consideration also mirror spiritual processes. ${ }^{30}$ These spiritual processes - we would say "emotions" - are the essence of music. Accordingly, the important thing about a musical work is not its structure, but rather its relationship to the emotional processes of which it is the expression. This results in an aesthetic position largely dependent on conception and reception, which Hausegger refers to as aesthetics from within [von Innen].

Hausegger grounds the successful communication between artist and recipient in the structural similarity of their bodies. ${ }^{31}$ If music consists of emotion, it must therefore awaken the same physical-spiritual response in the listener as that of the creator, for it is the direct expression of that common internal state. Aesthetic reception is dependent upon this empathetic feeling [Mitempfindung]; at the moment of sounding, communicator and recipient, artist and public are one. It is just such an aesthetic position which Eduard Hanslick terms as "pathological" in Vom Musikalisch-Schönen.

Under aesthetics from within, a work of art is understood on the basis of the mental or spiritual processes of the creator, and the question of aesthetic worth is inseparably bound up with those of impulse, inspiration, and manifestation of the artistic personality in music. Art is unconsciously created as a consequence of an aroused physical-spiritual state. In short, Hausegger's is an aesthetic with a psychological way of looking at things.

28 Hausegger, Die Musik als Ausdruck, 7-14. First ed. published serially in the Bayreuther Blätter $7(1884)$ and as a book in 1885.

29 E. J. Danz expresses it nicely as follows: "Musik ... ist das nach außen gekehrte Innere der Gefühle (Die Objektlose Kunst: Untersuchungen zur Musikästhetik Friedrich von Hauseggers, 168).

30 Hausegger develops this notion in his study of artistic creation, Das Jenseits des Künstler (1893).

31 Hausegger, Die Musik als Ausdruck, 27. 
If an aesthetic from within is one which, in Hausegger's words, "seeks the artistic object not in its concrete, objective, representative processes but in its internal processes," 32 then the objective form of a work of art is of less consequence than the subjective emotional processes of which it is the external expression. The beautiful is located not in the work itself, but in the expression of the artist. ${ }^{33}$ The work itself becomes merely a communicative channel between artist and public. Danz argues that this ontological "objectlessness" is the central concept underlying all of Hausegger's thought. ${ }^{34}$

Hausegger's conception of an aesthetic from within is an attempt at synthesising the empirical and speculative methods. Unlike men such as Helmholtz or Stumpf who drew a clear line between scientific research and aesthetics, Hausegger tried to effect a smooth shift between the two by elevating his physiological and psychological discoveries to an artistic-philosophical conceptual system.

In his Aesthetic as a Science of Expression and General Linguistic, Benedetto Croce discusses a late nineteenth-century fusion of science and philosophy which he terms "positivistic and evolutionary metaphysics." ${ }^{35}$ His definition of it as "a confused substitution of natural for philosophical sciences, and a hotchpotch of materialistic and idealistic, mechanical and theological theories" (ibid.) seems almost tailor-made for Hausegger. Although his inquiries were really conducted on inherently philosophical principles, Hausegger, whether through hypocrisy or merely deluded belief, insisted that he followed the methods of the natural sciences.

\section{Applied Aesthetics}

By way of concrete example, we now turn to two separate but related applications of the theory that music is expression: Hans von Wolzogen's Musikalischdramatische Parallelen and Curt Mey's Die Musikals tönende Weltidee (Music as the Sounding Idea of the World). Wolzogen's volume is even subtitled "contributions to an understanding of music as expression." Both works may be regarded as manifestations of the positivistic scientific impulse of the century, and of the Schopenhauerian-Wagnerian aesthetic that music consists of expres-

32 F. von Hausegger, “Aesthetik von Innen,” Bayreuther Blätter 18 (1893/95), 327.

33 Danz writes: "Beauty never resides in an object in itself, but rather always resides in the subjects which confront it" ("Schönes liegt niemals in einem Objekt an sich ... sondern stets in den zu ihm sich stellenden Subjekten," Die Objektlose Kunst), 159.

34 E. J. Danz, Die Objektlose Kunst, 316-19.

35 Benedetto Croce, Aesthetic as Science of Expression and General Linguistic, rev. ed., trans. by Douglas Ainslie (New York: Noonday Press, 1962), 388. 
sion, and is the highest of the arts. Mey opines that since art can never be merely empty form, Kunstwissenschaft and aesthetics can be built only on an idealistic philosophy; for a Wagnerian, Schopenhauer is the only choice. ${ }^{36}$ Wolzogen, too, reveals his Schopenhauerian colours when he remarks:

Music is the most human of all the arts, for it expresses the universally human not as a vague, hazy, patchy label, but in actuality, as an essence, a power, a truth: conceived aesthetically, an Idea. ${ }^{37}$

Both Wolzogen and Mey claim that their investigations do not touch the essence of the work of art, since this belongs to the noumenal realm, while their work is restricted to the level of appearance only. Their work particularly emphasises melody, which, according to Schopenhauer, marks the highest degree of the objectification of will, "the intellectual life and effort of man." ${ }^{38}$ As well, Hausegger's aesthetic of conception and reception as formulated in Musik als Ausdruck is employed by both Wolzogen and Mey to butress their proofs.

Hans von Wolzogen was the editor of the Bayreuther Blätter from its inception in 1878 until his (and the periodical's) death in 1938. He is perhaps best known as the author of the first of the infamous leitmotivic guides, or Leitfäden, to Wagner's works. Although he is frequently blamed for reducing Wagnerian operatic criticism to mere cataloguing of motives, Wolzogen by no means had such a narrow understanding of the works. ${ }^{39}$ His presentation of music resonates strongly with the thought of both Schopenhauer and Hausegger:

The musical motive is thus the audible expression of the Idea ... It seems specific to musico-dramatic art that everything, even the most external, will be shaped from the inside. ${ }^{40}$

36 Curt Mey, "Richard Wagner als Ästhetiker," Richard Wagner-Jahrbuch 1 (1906): 154. See also the first chapter of Mey, Die Musik als tönende Weltidee: Versuch einer Metaphysik der Musik. Erster Teil: Die metaphysichen Urgesetze der Melodik (Leipzig: Hermann Seemann, 1901).

37 "Die Musik ist die menschlichste Kunst; denn sie spricht das Allgemein-Menschliche wirklich aus, nicht als einen vagen, verschwommenen, gemischten Kartellbegriff, sondern als ein Wesen, eine Kraft, eine Wahrheit - ästhetisch gefasst: eine Idee." (Hans von Wolzogen, Musikalischdramatische Parallelen: Beiträge zur Erkenntnis von der Musikals Ausdruck (Leipzig: Breitkopf und Härtel, 1906), 108. First published serially in the Bayreuther Blätter, 1894-1903.

38 Schopenhauer, The World as Will and Idea, I, 335.

39 See Abbate and Parker, Analyzing Opera, 7-8.

40 "[D]as musikalische Motiv [ist] aber der hörbare Ausdruck der Idee ... So ist es das Eigentümliche der musikalisch-dramatischen Kunst, daß in ihr Alles, auch das Äußerlichste, von Innen herausgebildet wird" (Wolzogen, Musikalisch-dramatische Parallelen, 47). 
As for Hausegger, the process is from inside out. Drama finds expression in the music and the words remain almost incidental.

The main focus of Musikalisch-dramatische Parallelen is the systematic examination of certain musical gestures which recur again and again in Wagner's works. These Wolzogen terms "parallels." Like many of his contemporaries Wolzogen seems overcome by the urge to classify and collect data, and subdivides his one hundred examples into six different types: parallels of mood, feeling, situation, action, character, and declamation. According to Wolzogen, a parallel occurs when "the expressive themes of a work appear to be expressive gestures of music in general." 41 They are thus one level removed from that of leitmotive, which is restricted to individual works. ${ }^{42}$ While the coherence of the individual forms of the leitmotives provides the necessary unity for single works, parallels connect all works. The principle is Hausegger's notion that music is expression, which Wolzogen claims as received truth: "Music is expression. It expresses a feeling-content [Empfindungsgehalte]. Related feeling-contents correspond to related expressive gestures [Ausdrucksform]."

A philologist by training, Wolzogen perhaps naturally accepts the romantic "music as language" analogy. First, in the traditional fashion, music is seen as a metalanguage which expresses more - qualitatively and quantitatively - than any verbal language. ${ }^{44}$ Second, Wolzogen likens each of his parallels to a "word" in Wagner's musico-dramatic speech; such a language, he avers, is Wagner's mother tongue. He later refers to them as "Orphische Urworte," "Orphic primal words" of feeling. ${ }^{45}$ Central to all of this of course is the figure of Wagner: "the genius [Wagner] hovers over the elements of musical expression and out of them - of necessity - creates his work of art, just as he creates his conversations and literary works out of his mother tongue." ${ }^{\prime 46}$

41 “... wo die Ausdrucksthemen eines Werkes als Ausdrucksformen der Musik überhaupt erscheinen ..." (Wolzogen, Musikalisch-dramatische Parallelen, 7).

42 Regarding the difference between a parallel and a leitmotive, the latter is dependent upon the poem to give it its meaning, while the former is not; accordingly, leitmotives are recognised first, owing to the strong profile given them by the drama. Parallels become leitmotives as they are applied to a specific text. In "Leitmotive," Wolzogen ("Leitmotive," Bayreuther Blätter 20 [1897], 328) expresses the difference in the following fashion: "Leitmotive - Musik als Form; Parallelen - Musik als Ausdruck."

43 "Musik ist Ausdruck. Sie drückt Empfindungsgehalte aus. Verwandten Empfindungsgehalten entspricht verwandte Ausdrucksform" (Wolzogen, Musikalisch-dramatische Parallelen, 7).

44 "Soviel mehr sagt die Musik als das Wort!" (Wolzogen, Musikalisch-dramatische Parallelen, 121).

45 Wolzogen, Musikalisch-dramatische Parallelen, 71.

46 "Der Genius schwebt hier über dem Elemente des musikalischen Ausdrucks und schafft daraus sein Kunstwerk mit Nothwendigkeit, wie er aus seiner Muttersprache seine Reden und Dichtungen 
Our second concrete application of Hausegger's aesthetics is in some ways simply a more extreme version of Wolzogen's Musikalisch-dramatische Parallelen: Curt Mey's Die Musikals tönende Weltidee. Unlike Wolzogen, Mey was a trained musicologist, having studied musicology and philosophy (the required second area of concentration) in Berlin and Leipzig. He spends a considerable amount of time setting the philosophical framework for his investigation, systematically beginning with the idealistic-materialistic split, and carefully explaining why he has settled upon Schopenhauer:

However, several things have caused me to base my investigations into the essence of music especially on Arthur Schopenhauer's system of metaphysics. First, I am completely and deeply convinced of the correctness of the fundamentals of this philosopher's teachings. Second, Schopenhauer enjoys the enthusiastic approval of Richard Wagner, by far the greatest modern artist and the greatest musician so far; Wagner, who, on the one hand first reached the clearest perception of the deepest essence of art - such as his own most sublime works (which I will hopefully succeed in the following investigation to prove to be the best source for research into the innermost essence of music) - through the metaphysics of the Frankfurt philosopher, and who, on the other hand, however, virtually proves in fact the correctness of Schopenhauer's teaching of the metaphysics of music through his own highly significant works; Wagner, who also finally expanded Schopenhauer's metaphysics of music in his Festschrift Beethoven. ${ }^{47}$

schafft" (Wolzogen, Musikalisch-dramatische Parallelen, 15). A corollary of Wolzogen's analogy between parallels and words is invoked when theoretically parallel passages turn out to be less so in practice. This might be called the "cognate escape clause," for it revolves around words such as "vier" and "quattuor" which are radically different in different languages; see Wolzogen, ibid., 17-18 and passim and Wolzogen, "Leitmotive," 329.

47 "Was mich nun aber hauptsächlich veranlaBt hat, meine Untersuchungen uber das Wesen der Musik ganz speziell auf dem metaphysischen System Arthur Schopenhauers aufzubauen, das hat verschiedentliche Gründe. Erstens bin ich ... von der Richtigkeit der Lehre dieses Philosophen in ihren Grundtheorien vollkommen und auf das tiefste überzeugt. Zweitens erfreut sich Schopenhauer der begeisterten Zustimmung Richard Wagners, des bei weitem größten modernen Künstlers und des bisher größten Musikers überhaupt, welcher einerseits durch die Metaphysik des Frankfurther Philosophen erst zur klarsten Vernunfterkenntnis des tiefsten Wesens der Kunst, wie seiner eigenen, erhabensten Kunstwerke, gelangte, andrerseits aber durch seine bedeutendsten Kunstwerke (welche als die vorzüglichste Quelle für die Erforschung des innersten Wesens des Musik nachzuweisen, mir hoffentlich in meinen folgenden Untersuchungen gelingen wird) geradezu die Richtigkeit der Lehre Schopenhauers von der Metaphysik der Musik als thatsächlich beweist und endlich in der Festschrift 'Beethoven' Schopenhauers Metaphysik der Musik erweitert hat" (Curt Mey, Die Musik als tönende Weltidee, 4-5). 
At several places in his text, Mey repeats his admonition that one must understand the teachings of Schopenhauer and Wagner in order to comprehend his work. Mey's adoption of Schopenhauer's philosophy is not restricted to Schopenhauer's thoughts on music or general premises. Throughout his text, Mey notes that this or that musical phenomenon "proves" a particular theory of Schopenhauer, and devotes an entire chapter to the interpretation of the prelude to Das Rheingold as embodying various degrees of objectification of the will (from the inanimate to the animate).$^{48}$ Mey's premise is one which we have already encountered in Schopenhauer, Wagner, Hausegger, and Wolzogen: music is the sounding idea of the world:

If music is the sounding will of the world, that is, the sounding universal will, so it is also the only will of any idea which all the Ideas of the universe brings to expression; consequently, for each Idea there is a precise sounding expression, just as there is as well for each movement of the will, whether in nature, in macrocosm, or in humans, in microcosm. Music is the sounding idea of the world, which however does not reveal itself as such directly to the human ear, but to begin with to the intuitively seeing and writing musican alone ... As soon as the seeing musician becomes a composing musician, he objectifies the conceived Idea, brings it to appearance, and makes it a representation; however, only in one-dimensional sounding time. Through this, after all, the Idea loses its completeness; in fact, the less so the greater the genius of the composer is; the less he otherwise conforms to the boundaries of the world of appearances, the less he forces them into more or less arbitrary, stereotypical forms ... However, in so far as music, effective only temporally, moves in only one dimension in the world of appearances, it certainly stands between essence [Dingansich] and appearance. Thus music acquires its boundary lines and in so doing, draws closer to the first essence, which it conveys in a relatively pure fashion in that it above all speaks only to our wills, to our feelings. Only partially and from

48 For example, the fact that the motivic complex associated with Siegmund and Sieglinde's love in the first act of Die Walküre conforms to a particular type of Erkenntnismotiv (motives which predominately descend then ascend) which Mey terms "Wahnmotive," leads him to assert that this "proves" the correctness of Schopenhauer's conception of sexual love: Love is deception, an illusion; it is the ultimate assertion of the will, the will to live and reproduce. Mey's Wahnmotive are in fact all related to the ill-named "Fluchtmotiv," which Deryck Cooke held to be a type of Urmotiv connected with love in Wagner's works. For an evaluation of this claim, see Jeffrey L. Stokes, Contour and Motive: A Study of "Flight" and "Love" in Wagner's 'Ring,' 'Tristan,' and 'Meistersinger'" (Ph.D. dissertation, State University of New York at Buffalo, 1984). 
time to time does it also speak to our reason and understanding, and only through this mediation. ${ }^{49}$

As is perhaps already suspected, Mey also accepts the music/speech analogy so common to the romantics. Regarding the "wunderbare Sprache der Musik," Mey asserts that

it gives us information about the essence of the world; because [music] originally and even now stands beyond all appearance and still is no real representation, it expresses rather the sounding will for our feelings and our minds. ${ }^{50}$

What is particularly interesting about Mey's book is its positivistic and systematic presentation. Like Wolzogen, Mey traces the recurrence of certain musical gestures in different works, but Mey does not restrict himself solely to Wagner's works (although Wagner does provide the greatest number of Mey's examples). These gestures, which Mey calls Urmotive, are presented as empirical evidence for the theory that music is expression. His is a "Kunstwissenschaftlichen Forschung" with the professed aim being "to determine the feeling-content of music through scientific-philosophical means." ${ }^{51}$ To

49 "Wenn die Musik tönender Wille der Welt ist, also tönender Universalwille, so ist sie auch im einzelnen Wille jeglicher Idee, da das Universum sämtliche Ideen zur Erscheinung bringt; für jede Idee giebt es somit einen bestimmten tönenden Ausdruck; ebenso aber auch für jede Willensregung, sei es in der Natur, im Makrokosmos, oder aber im Menschen, im Mikrokosmos ... Die Musik ist die tönende Weltidee, offenbart sich aber als solche nicht direkt dem leiblichen Ohre, sondern zunächtst nur dem intuitiv schauenden, dichtenden Musiker ... Sobald der schauende Musiker zum komponierenden Musiker wird, objektiviert er die erschaute Idee, bringt sie zur Erscheinung, macht sie zur Vorstellung, jedoch nur in der eindimensionalen, tönenden Zeit. Hierdurch büßt die Idee immerhin an ihrer Vollkommenheit ein, und zwar um so weniger, je größer das Genie des Komponisten ist und je weniger er sie sonst den Schranken der Erscheinungswelt anpaßt, je weniger er sie in mehr oder weniger willkürliche, stereotype Formen hineinzwängt ... Insofern aber, als die einzig in der Zeit wirkende Tonkunst eben nur eindimensional in die Erscheinung tritt, steht sie gewissermaßen zwischen 'Ding an sich' und Erscheinung, bildet also ihre Grenz- und Scheidungslinie und nähert sich dabei noch mehr dem ersteren, das sie verhältnismäßig rein vermittelt, indem sie vor allem nur zu unserem Willen, zu unserem Gemüte, und erst durch dessen Vermittelung teilweise und bisweilen auch zu unserem Verstande und zu unserer Vernunft spricht" (Mey, Die Musik als tönende Weltidee, 33, 35).

50 “... sie giebt uns Auskunft über das Wesen der Welt; weil sie eben ursprünglich schon jenseits aller Erscheinung steht und noch keine eigentliche Vorstellung ist, vielmehr den tönenden Willen für unser Gefühl und unser Gemüt, d.h. für uns als Wille, zum Ausdruck bringt"(Mey, ibid., 190).

51 “... den Gefühlsinhalt der Musik mehr oder weniger auf wissenschaftlich - philosophischem Wege zu bestimmen" (Mey, ibid., 321). 
this end, Mey identifies five "metaphysiche Urgesetze" which apply to melodies, or motives, all predicated on the fact that "each motive has a completely precise emotional content and that is why it is only applicable for the representation of an equally precise circle of feelings." 52 These five laws are as follows:

1. All ascending melodies signify an affirmation of the will, the power of life and deeds, the desire for deeds, struggling, striving and longing in an affirmative sense, also rejuvenation through new creation; finally, as well, representation of all external ascending motion. We name all motives with purely ascending melodies Affirmation-motives, as well as Becoming-motives.

2. All descending melodies signify a denial of the will, displeasure, renunciation, despair, urging and longing in a negative sense, fading, death, also the taking-up [Aufgehen] of the individual in another individual or in Nirvana; finally, as well, representation of all external descending motion. We name all motives with purely descending melodies, Negation- or Fading-motives.

3. All ascending and then descending melodies signify unconscious being, the will of the species or the individual will, life in nature, singly or in whole, as well as vegetative and purely animal life in men, finally, human emotions, passions, and moods. We call motives which ascend and then descend Willmotives, or Instinct-motives [Webmotive].

4. All descending and then ascending melodies signify conscious being, knowledge (particularly that of the individual will illuminated by knowledge), the life of the individual as opposed to the instinct [Weben] of the individual and the species. We call motives which descend and then ascend Life-motives, or Knowledge-motives.

5. The smaller an interval, the more individual its significance; the larger, the more general..$^{53}$

52 "jedes Motiv hat einen ganz bestimmten Gefühlsinhalt und ist daher nur zur Darstellung eines ebenso bestimmten Empfindungskreises verwendbar" (Mey, ibid., 341). When Mey speaks of motives or melodies he does so in an elevated and abstracted sense; a motive is a leitmotive only in its external manifestation in the drama, internally, "really," it is a parallel (although Mey does not use the word).

53 1) Alle aufsteigende Melodik bedeutet Willensbejahung, Lebens- und Thatkraft, Thatenlust, Ringen, Streben und Sehnen im bejahenden Sinne, dann Verjüngung durch Neuerzeugung; endlich auch Darstellung aller äusserlich aufsteigenden Bewegung. Wir nennen alle Motive mit rein aufsteigender Melodik Bejahungsmotive oder auch Werdemotive; 2) Alle absteigende Melodik bedeutet Willensverneinung, Unmut, Entsagung, Verzweiflung, Drängen und Sehnen im verneinenden Sinne, Vergehen, Tod, dann Aufgehen des Individuums im anderen Individuum oder im Nirvana; endlich auch Darstellung aller äußerlich absteigenden Bewegung. Wir nennen alle Motive mit rein absteigender Melodik Verneinungs- oder Vergehmotive; 3) Alle auf- + absteigende Melodik bedeutet unbewußtes Dasein, den Gattungs- oder Individualwillen, das 
According to Mey, these laws apply without exception to all music ("Es giebt nur eine wahre Musik!") and are just as immutable as natural laws.

The very presentation of Die Musik als tönende Weltidee reveals Mey's strong positivistic inclinations. Certainly, as we have seen, the search for natural laws to explain phenomena is one typical of a scientific approach. ${ }^{54}$ The systematic structure of the book itself attests to Mey's sympathy with the methods of science. Conclusions are based on empirical evidence: a chapter is devoted to each of the first four laws, and case after case is presented for the reader's consideration. Mey, like Wolzogen, succumbs to the urge to classify, and catalogues various sub-groupings of Affirmation-, Negation-, Will-, and Lifemotives. These sub-groupings are in fact examples of what Wolzogen would term a parallel; Mey regards them as rather more concrete manifestations of his fundamental law. Finally, Mey provides examples of the workings of his laws in complete musical pieces: folksongs, artsongs, operatic arias, Beethoven overtures, and the like.

\section{The Magic Wand of the Wagnerians}

It need hardly be emphasised that the aesthetic of expression is diametrically opposed to that of Hanslick and the formalists. ${ }^{55}$ In fact the basis for comparison

Leben in der Natur, im einzelnen und im ganzen, sowie das vegetative und rein animalische Leben im Menschen, endlich dessen Gemütsbewegungen, Leidenschaften und Stimmungen. Wir nennen Motive mit auf- + absteigende Melodik Willens- oder Webmotive; 4) Alle ab- + aufsteigende Melodik bedeutet bewußtes Dasein, die Erkenntnis, beziehentlich den von der Erkenntnis beleuchteten Einzelwillen, das individuelle Leben im Gegensatz zum Weben des Individuums und der Gattung. Wir nennen Motive mit ab- + aufsteigender Melodik Leb- oder Erkenntnismotive; 5) Je kleiner ein Intervall, desto individueller, je größer ein Intervall, desto genereller ist seine Bedeutung (Mey, ibid., 186, 199-200, 214, 258, 111).

54 At this point, I am obliged to temper somewhat my earlier comment about Wolzogen's and Mey's Schopenhauerian reliance on melody as the basis for their investigations. This indeed seems to be the case with Mey when objectively examining Die Musik als tönende Weltidee, but Mey in two instances notes that he is deliberately restricting his investigation to melody alone, and that harmony, rhythm, and dynamism [Dynamik] are just as important to the music. He is convinced that equally encompassing and valid metaphysical laws remain to be found for these musical parameters. See Mey, ibid., 321-22.

55 Hanslick's aesthetic of the "specifically musical" is also a product of the intellectual climate of the second half of the century. In many respects it is his Vom Musikalisch-Schönen which is an untainted manifestation of the positivistic impulse of the age. Part of the reason that Hausegger's Musik als Ausdruck was received so enthusiastically was that it gave Hanslick's opponents the appearance of an equally firm scientific basis from which to argue. See, for example, Arthur Seidl, Vom Musikalisch-Erhabenen: Prolegomena zur Aesthetik der Tonkunst (Regensburg: M. Wasner, 1887). 
is narrow, as both stem from entirely different value judgements and criteria. While the formalist aesthetic is concerned with art as an absolute and autonomous entity, Hausegger's expressive aesthetic is more concerned with art as a medium of human communication, as a medium of human relationships. The formalist aesthetic is more directly concerned with the work of art itself than is the expressive aesthetic in which the work of art itself is important only as a communicative channel between the psyche of the artist and that of the recipient. For the Wagnerian camp, music's action extended beyond the structure of the score, involving more than was admitted by Hanslick and his followers, for whom investigation of the beautiful means investigation of the structure of the work, without any consideration of the creative process. While Hanslick restricts the signifying power of music to purely musical matters (it signifies nothing but itself), it is a given in Hausegger's aesthetic that music communicates feelings. To Hausegger and his followers, Hanslick and his are trapped in the world of appearance, examining only the external shell of a work and missing the core. ${ }^{56}$ This polarity between objectivity and subjectivity expresses itself in a series of binarisms which remain influential (rightly or not) even today: form/expression; conservative/modern; Brahms/Wagner; Hanslick/Hausegger. Even the idea that Hanslick presents an aesthetic of absolute music requires revision when seen through the lens of the expressive aesthetic. Carl Dahlhaus has noted the double significance of the term "absolute" in the nineteenth century: "absolute" in the sense of being divorced from a specific programme or expressive intent, and "absolute" as an intimation of the Absolute, the Ding-an-sich. ${ }^{57}$ Schopenhauer, Wagner, Wolzogen, and Mey all subscribe to the second of these, while Hanslick adheres to the first. Thus Mey can claim that Hanslick's aesthetic has nothing to do with absolute music. ${ }^{58}$

To return to my initial point, at the end of the nineteenth century Wagner's supporters and Wagner's critics were not really engaged in dialogue, but were rather talking at cross purposes, for, as we have seen, the theory of music as expression is not only incompatable with but also incomparable to that of the formalists. The attempted reconciliation of these two positions would not take

56 For example, Mey rhetorically asks whether or not Hanslick and his followers ought not "to consider that they always observe only the external significance, the shell of the music, however, not its heart, or even its heart and shell together in their mutual relationship." [bedenken, daß sie immer auch nur die äußere Bedeutung, die Schale der Musik betrachten, nicht aber ihren Kern, oder gar Kern und Schale zugleich und in ihrem gegenseitigen Verhältnis.] In conclusion he adds, "but what is Schopenhauer to them?!" Mey, Die Musik als tönende Weltidee, 15n.1.

57 Carl Dahlhaus, The Idea of Absolute Music, trans. Roger Lustig (Chicago: University of Chicago Press, 1989).

58 Mey, Die Musik als tönende Weltidee, 342. 
place until the 1920s and 1930s with the work of Alfred Lorenz, who claimed that in his method "an aesthetic of expression ... and an aesthetic of form blend into one." 59

That today Brahms and Hanslick are generally linked in opposition to Wagner - with nary a mention of Hausegger - in histories of the later nineteenth-century is indicative of how little known the expressive aesthetic position has become. Part of the problem, of course, was that many Wagnerians needed no rational explanation for the power which Wagner's works exercised over them. But clearly some did, and the expressive aesthetic assumed a position of importance and influence well into the twentieth century. If today we find it rather curious, this is by no means to be dismissive of its contemporary importance, both musical and philosophical. Rather, our incomprehension is indicative of the shift of what Hans Robert Jauss would call our "horizon of expectation," the perceptual space between then and now. ${ }^{60}$ Symptomatic of this incomprehension is the 1971 quotation from Winfried Schüler which provided me with the image in my title; Schüler writes:

Even the methodologically strict investigations of a Friedrich von Hausegger ... or a Kurt Mey are not able to hide the fact that scientific systems had been little valued in Bayreuth. With the notion of "art as expression" they believed that they held in their hands the magic wand which could remove all aesthetic problems with one strike. ${ }^{61}$

59 “Ausdrucksästhetik ... und Formalästhetik ... verschmelzen in eins" (Alfred Lorenz, Das Geheimnis derForm bei RichardWagner, Bd. 4:Der Musikalische Aufbau von Richard Wagners 'Parsifal.' (Berlin: Max Hesse, 1933; repr. Tutzing: Hans Schneider, 1966), 192n.2.

60 Leon Botstein ("Review Essay: Between Aesthetics and History," 19th-Century Music 13 [1989], 168) has recently written: "the aesthetics of nineteenth-century music appear increasingly historical and discontinuous with contemporary sensibilities. It has become evident that ... the surface of nineteenth-century musical values must be penetrated."

61 "Auch die methodisch strengen Untersuchungen eines Friedrich von Hausegger, eines Arthur Seidl oder Kurt Mey vermögen nicht darüber hinwegzutäuschen, daß wissenschaftliche Systematik in Bayreuth sehr klein geschrieben wurde ... Mit dem Begriff der Ausdruckskunst glaubt man den Zauberstab in der Hand zu halten, der alle ästhetischen Probleme auf einen Schlag zu lösen vermag" (Winfried Schüler, Der Bayreuther Kreis von seiner Entstehung bis zum Ausgang der Wilhelminischen Ära: Wagnerkult und Kulturreform im Geiste völkischer Weltanschauung, vol. 12: Neue Münstersche Beiträge zur Geschichtsforschung, ed. Heinz Gollwitzer (Münster: Aschendorff, 1971), 198. 


\begin{abstract}
As is well-known, throughout most of the nineteenth century the defence of Wagner's music was not undertaken on the same grounds on which it was attacked. Critics such as Ludwig Bischoff and Eduard Hanslick attacked Wagner's music for its alleged "formlessness" and harmonic illogicalities, while Wagner's partisans countered with appeals to vaguer criteria of beauty and truthfulness, couched generally in leitmotivic terms, often focusing on the so-called "symphonic web" of Wagner's late works.

One particular strategy is encapsulated by the phrase "Musik als Ausdruck," which forms the basis of a number of late nineteenth- and early twentieth-century monographs and articles about Wagner's works. Musical gestures were held to encode a particular emotional state and to reawaken that state in the listener, who would intuit the "meaning" of the gesture instinctively; within such an aesthetic, music was held to represent the essence of phenomenon, the "thing-in-itself."

This article attempts to provide an account of the dual foundations of this aesthetic paradigm in philosophy and science, as manifested by Arthur Schopenhauer's Die Welt als Wille und Vorstellung and by Friedrich von Hausegger's Die Musik als Ausdruck respectively, and suggests that the resulting position - as articulated by Hans von Wolzogen and Curt Mey - is not only incompatible with but also incomparable to that of the formalists. The reconciliation of these two positions would not take place until the 1920s and 1930s with the work of Alfred Lorenz.
\end{abstract}

